\title{
地方創生関係交付金を活用した 越境連携事業の実態把握
}

CROSS-BORDER COOPERATION
PROJECTS USING THE NATIONAL
GOVERNMENT'S GRANT FOR
REGIONAL REVITALIZATION

小川勇樹 — $* 1$ 戸田敏行 — $* 2$

キーワード :

地方創生, 越境連携, 遠隔連携

Keywords:

Regional revitalization, Cross-border cooperation, Remote cooperation
Yuki OGAWA

This study investigates the implementation of cross-border cooperation projects in regional cooperation projects that were adopted under the national government's grant. In addition, we interviewed individuals from the relevant municipalities to clarify the nature of their cooperation in the project. Our research determined 118 cross-border cooperation projects among 592 regional cooperation projects that were initiated under the grant. These projects can be categorized into two types. The first involves cooperation between neighboring municipalities, and the second involves cooperation between remote municipalities.

\section{1. はじめに}

\section{1 研究の背景と目的}

現在，人口減少への対応と東京一極集中の是正を背景に自律的で 持続可能な地域の創生を目指す ${ }^{1)}$ 地方創生が国の主要政策として実 施されている，その地方創生では地域間連携が重視されている。例 えば，地方創生に関連した先駆的事業に対して交付される地方創生 関連交付金では注1)，先駆性の評価基準の一つとして，広域にわたる 複数の地方公共団体が，適切に連携して同一事業を実施する「地域 間連携」を挙げており，この地域間連携による事業「広域連携事業」 を申請する場合は, 申請可能な事業数が追加される注 2).

このように地方創生において地域間連携は地域課題解決の重要な 手段であり，地域間連携による事業の実態を分析して効果的に活用 することが必要である. その地域間連携には同一県内での連携(以下, 県内連携）と県境を越えた連携（以下，越境連携）があり，近年は 大規模自然災害や鳥獣害への対応から越境連携が注目されている。

こうした背景から，本研究では地方創生関倸交付金で地域間連携 による事業として採択された「広域連携事業」に着目し，その中で もより広域性の高い県境を越えた広域連携事業を「越境連携事業」 と定義して実態を分析する。

\section{2 既往研究と本研究の位置付け}

越境連携に関する研究は, (1)越境連携の必要性に関する研究と(2) 越境連携の実態分析に関する研究がある.

越境連携の必要性に関寸る研究には，県境に接する市町村（以下， 県境自治体）を対象にアンケート調查を実施した研究 ${ }^{2)}$ がある。そ れによれば，これまで実施された越境連携事業は観光に関する事業 が最も多く，その他には道路整備促進や消防・防災に関する事業が 実施されている。そして，今後必要な事業は医療連携や県境部の不 法投棄対策，鳥獣害対策など単独自治体では解決が困難な課題であ
り, 越境して連携することで課題解決が期待されている. また, 戸田 ${ }^{3)}$ によれば現在の国 - 都道府県 - 市町村の行政構造では県境を越えた 連携は難しく，そのため県境を越えて市町村が連携する越境連携は 広域連携の中でも地域計画の策定や連携から事業実施までのプロセ スに独自性があることが指摘されている.

次に，越境連携の実態分析に関する研究には，県境地域で活動す る連携組織や活動家の活動実態を分析した研究などがある ${ }^{4)}$ 5) 6). 戸 田らは県境を越えた連携活動について連携活動実施者を対象にアン ケート調査を実施している ${ }^{5)}$ ，そして調査で判明した 116 連携活動に ついて活動分野，活動主体，活動の空間的広がり，活動組織の連携 方式を明らかにしている。 また，国土交通政策研究所 ${ }^{6)}$ は，47 都道 府県庁と越境連携実施組織を対象に越境連携事業に関するアンケー 卜調査を行い, 越境連携事業 117 事業について事業概要, 実施理由, 事業効果と負担，県を越えることで伴う影響，実施体制を明らかに している. 加えて, 事業主体に行ったヒアリング調査から連携事業 のきっかけは首長のトップダウン，国の支援制度への応募，共通す る問題解決のためといった内容が明らかにされている.

以上のように，越境連携は全国で実施され，その必要性と独自性 から，これまで越境連携事業の実態分析が進められて活動主体や活 動空間の範囲, 連携のきっかけや効果・課題等が明らかにされている. また，これまで国の主導により地域連携軸構想や定住自立圈構想等 の広域連携が推進され，多くの研究が蓄積されている注3) が，必ずし も越境連携に着眼したものではない。そこで, 本研究は国が主導す る地方創生において現在進められている広域連携事業の中でも越境 連携事業に着目する。交付金に採択された越境連携事業は地域課題 を克服する先駆的事業注2) であり，将来的な事業の自立性や事業推進 主体の形成等が確保されている事業である. 採択された越境連携事 業の把握と連携から実施までのプロセス及びその連携効果を明らか

本稿は 2017 年越境地域政策研究フォーラムにおいて口頭発表した内容を加筆・修正したものである.

愛知大学三遠南信地域連携研究センター 助教・博士 (人間環境学)

(T 441-8522 愛知県豊橋市町畑町 1-1)

2 愛知大学地域政策学部 教授・博士 (工学)
Assist. Prof., Research Center for San-En-Nanshin Regional Collaboration, Aichi Univ., Ph.D.

Prof., Faculty of Regional Policy, Aichi Univ., Dr. Eng. 
にすることで，交付金を活用した越境連携の実態について把握する.

\section{3 研究の方法}

本研究では, 2016 年度までに交付された地方創生先行型交付金（以 下, 先行), 地方創生加速化交付金の 1 次及び 2 次（以下, 加速化, 加速化 2 次), 地方創生推進交付金の第 1 回目及び第 2 回目（以下, 推進 1, 推進 2）を対象に，まち・ひと・しごと創生本部 HP で公開 されている採択事業一覧 ${ }^{7)}$ 11) から広域連携事業のうち越境連携事 業の採択状況及び実施構成等について把握する. 次に, 特徵的な越 境連携事業を取り上げ，その実施計画書分析と事業実施自治体への ヒアリングから越境連携事業の連携経緯や事業内容, 事業の効果に ついて明らかにする.

\section{2. 地方創生関係交付金を活用した越境連携事業}

本章では地方創生関係交付金の交付対象決定に関する資料 $\left.{ }^{7)} \sim 11\right)$ をもとに，地方創生関係交付金で採択された広域連携事業における 越境連携事業の採択状況及び事業実施構成を把握する.

\section{1 広域連携事業の種別と採択状況}

地方創生関係交付金による事業は単独自治体が実施する「通常 事業」と複数自治体が連携して実施する「広域連携事業」がある. 2015 年の先行から 2016 年の推進 2 までの交付金で採択された全事業 (「通常事業」と「広域連携事業」) は 4178 事業あり, そのうち広域 連携事業は 592 事業で全事業の $14.2 \%$ ある。.

その広域連携事業は, 県を跨いで自治体が連携する「越境連携事 業」と県内の自治体が連携する「県内連携事業」に分類できる（図 1）. 越境連携事業と県内連携事業に分類して交付金種別による採択 状況, 広域連携種別, 事業主体構成, 交付予定額について分析した 結果を表 1 に示す.

まず，越境連携事業と県内連携事業の採択数についてみると，県 内連携事業が 474 事業（80.1\%）であるが，越境連携事業も 118 事 業（19.9\%）ある。京越境連携事業の交付金別の採択状況をみる と先行で 22 事業 (18.6\%), 加速化で 69 事業 (58.5\%), 加速化 2 次で 1 事業 $(0.8 \%)$, 推進 1 で 14 事業 $(11.9 \%)$, 推進 2 で 12 事業 (10.2\%) 採択されており, 加速化でもっとも多くの越境連携事業が 採択されている，さらに，隣接する自治体が連携する事業を「隣接 連携」, 隣接しない遠隔の自治体が連携する事業を「遠隔連携」と細

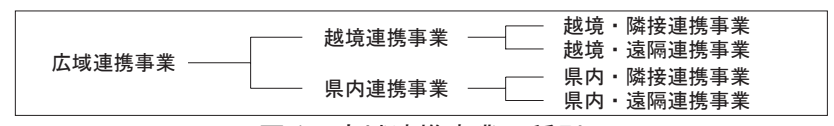

図 1 広域連携事業の種別

\section{表 1 広域連携事業の概要}

\begin{tabular}{|c|c|c|c|c|c|c|c|}
\hline & \multicolumn{6}{|c|}{ 広域連携 } \\
\hline & & \multicolumn{2}{|c|}{ 全体 } & \multicolumn{2}{|c|}{ 越境連携 } & \multicolumn{2}{|c|}{ 県内連携 } \\
\hline & & 事業数 & 比率 $(\%)$ & 事業数 & 比率 (\%) & 事業数 & 比率 (\%) \\
\hline \multicolumn{2}{|r|}{ 総計 } & 592 & $(100.0)$ & 118 & $(100.0)$ & 474 & $(100.0)$ \\
\hline \multirow{5}{*}{$\begin{array}{l}\text { 交付金 } \\
\text { 種別 }\end{array}$} & 先行 & 94 & (15.9) & 22 & $(18.6)$ & 72 & $(15.2)$ \\
\hline & 加速化 & 326 & $(55.1)$ & 69 & $(58.5)$ & 257 & $(54.2)$ \\
\hline & 加速化 (2次) & 11 & (1.9) & 1 & $(0.8)$ & 10 & $(2.1)$ \\
\hline & 推進(第1回) & 86 & $(14.5)$ & 14 & $(11.9)$ & 72 & $(15.2)$ \\
\hline & 推進(第2回) & 75 & $(12.7)$ & 12 & $(10.2)$ & 63 & $(13.3)$ \\
\hline \multirow{2}{*}{$\begin{array}{c}\text { 広域連携 } \\
\text { 種別 }\end{array}$} & 隣接連携 & 418 & $(70.6)$ & 60 & $(50.8)$ & 358 & $(75.5)$ \\
\hline & 遠隔道 & 174 & $(29.4)$ & 58 & $(49.2)$ & 116 & (24.5) \\
\hline \multirow{3}{*}{$\begin{array}{c}\text { 事業主体 } \\
\text { 構成 }\end{array}$} & 市町村連纬 & 378 & (63.9) & 73 & $(61.9)$ & 305 & $(64.3)$ \\
\hline & 県·市町村連携 & 181 & $(30.6)$ & 12 & $(10.2)$ & 169 & $(35.7)$ \\
\hline & 県連 & 33 & $(5.6)$ & 33 & $(28.0)$ & 0 & $(0.0)$ \\
\hline \multirow{3}{*}{$\begin{array}{c}\text { 事業 } \\
\text { 主体数 }\end{array}$} & 2団体 & 225 & $(38.0)$ & 52 & $(44.1)$ & 173 & $(36.5)$ \\
\hline & 3団体以上 & 367 & $(62.0)$ & & $(55.9)$ & 301 & $(63.5)$ \\
\hline & 平均値/中央値 (団体) & \multicolumn{2}{|c|}{$4.5 / 3.0$} & \multicolumn{2}{|c|}{$4.2 / 3.0$} & \multicolumn{2}{|c|}{$4.6 / 3.0$} \\
\hline \multirow{5}{*}{$\begin{array}{l}\text { 交付 } \\
\text { 予定額 }\end{array}$} & 1千万未満 & 106 & $(17.9)$ & 23 & (19.5) & 83 & $(17.5)$ \\
\hline & 5千万末満 & 242 & $(40.9)$ & 46 & $(39.0)$ & 196 & $(41.4)$ \\
\hline & 1億未満 & 123 & $(20.8)$ & 24 & $(20.3)$ & 99 & $(20.9)$ \\
\hline & 1 億以上 & 121 & $(20.4)$ & 25 & $(21.2)$ & 96 & $(20.3)$ \\
\hline & 平均値/中央値 (千円) & 66,205 & 36,686 & 74,011 & 34,975 & 64,261 & 37,700 \\
\hline
\end{tabular}

分した結果では, 越境連携事業のうち「隣接連携」が 60 事業 (50.8\%), 「遠隔連携」が 58 事業 (49.2\%) と同程度ある。

次に，事業主体構成についてみる。事業主体が市町村だけの構成 を「市町村連携」, 県と市町村の構成を「県・市町村連携」, 県だけ の構成を「県連携」として分類した。 その結果, 越境連携事業と県 内連携事業ともに，「市町村連携」による事業が $61.9 \%$ と $64.3 \%$ で 最も多く, 越境連携事業では「県連携」が $28.0 \%$, 県内連携事業で は「県・市町村連携」が $35.7 \%$ で続く。このように, 県を跨ぐ越境 連携事業の 6 割は市町村連携である.

事業主体数については，越境連携事業と県内連携事業ともに「3 団 体以上」による事業が 6 割を占めるが，「2 団体」（1 対 1) による事 業も 4 割ある. 事業主体数の平均值は越境連携事業が 4.2 で県内連 携事業の 4.6 と比較して少ない，そして，越境連携事業の方が「2 団 体」による事業割合が多いことからも，少数主体で実施されている.

最後に交付予定額についてみると, 越境連携事業と県内連携事業 ともに「 1 千万〜 5 千万円未満」の事業が最も多い，交付予定額の平 均值は越境連携事業が 74, 011 千円で県内連携事業の 64, 261 千円よ りも高いことが分かる.

\section{2 広域ブロック別の越境連携事業の実施状況}

越境連携事業の実施状況を広域ブロック別に把握するために, 全 118 事業について実施主体が位置するブロックをカウントした結果が 表 2 である. なお, ブロックを跨ぐ事業については, 各々のブロッ クでカウントした，広域ブロックについては広域地方計画を参照注4) し，沖縄県は九州圈の中に組入れた .

越境連携事業への関与が最も高いブロックは東北圈と九州圈で ともに $31.4 \%$ である.以降は中部圈と中国圈が $25.4 \%$, 首都圏が $22.9 \%$ で続く. 越境連携事業をさらに隣接連携と遠隔連携に区分し た結果をみると，隣接連携の事業は中国圈が $26.7 \%$ で次に九州圈が $23.3 \%$ で高い，遠隔連携の事業は東北圈が $50.0 \%$ で最も高く，九州 圈が 39.7\%, 中部圈が $32.8 \%$, 首都圈が $31.0 \%$ で続く.

このように, 越境連携事業への関与が高い東北圏と九州圏である がそれぞれ特徴がある. 東北圈は越境連携事業でも遠隔連携の割合 が高い。これは東日本大震災を契機に広域連携の必要性がいっそう 高まる中, 東北圈はその意識が強く遠隔連携事業に積極的に参画し ているのではないかと考えられる。, 一方, 九州圈は隣接連携と遠隔 連携のどちらの割合も高いといった特徴があり, 特にブロックとし て一体性が強いため隣接連携の割合が高いと考えられる.

\section{3. 市町村連携による越境連携事業の把握}

前章で越境連携事業は主に「市町村連携」による事業であること が分かった．地域づくりに最も直結している基礎自治体である市町 村は, 既往研究 ${ }^{3)}$ での指摘にもあるように国一都道府県一市町村の

\begin{tabular}{|c|c|c|c|c|c|c|}
\hline & \multicolumn{6}{|c|}{ 越境連携 } \\
\hline & \multicolumn{2}{|c|}{ 全体 } & \multicolumn{2}{|c|}{ 隣接 } & \multicolumn{2}{|c|}{ 遠隔 } \\
\hline & 事業数 & 比率 $(\%)$ & 事業数 & 比率 $(\%)$ & 事業数 & 比率 $(\%)$ \\
\hline 全国 & 118 & $(100.0)$ & 60 & $(100.0)$ & 58 & $(100.0)$ \\
\hline 北海道 & 12 & (10.2) & 0 & $(0.0)$ & 12 & $(20.7)$ \\
\hline 東北圈噌 & 37 & (31.4) & 8 & $(13.3)$ & 29 & $(50.0)$ \\
\hline 首都圏 & 27 & (22.9) & 9 & $(15.0)$ & 18 & $(31.0)$ \\
\hline 北陸圈 & 17 & (14.4) & 8 & (13.3) & 9 & (15.5) \\
\hline 中部圏 & 30 & (25.4) & 11 & (18.3) & 19 & (32.8) \\
\hline 近畿圈 & 22 & (18.6) & 10 & (16.7) & 12 & $(20.7)$ \\
\hline 中国圏 & 30 & $(25.4)$ & 18 & $(30.0)$ & 12 & $(20.7)$ \\
\hline 四国圏 & 11 & (9.3) & 2 & (3.3) & 9 & (15.5) \\
\hline 九州圈 & 37 & $(31.4)$ & 14 & (23.3) & 23 & (39.7) \\
\hline
\end{tabular}


表 3 市町村連携による越境連携事業の概要

\begin{tabular}{|c|c|c|c|c|c|c|c|}
\hline & \multicolumn{6}{|c|}{ 市町村連携による越境連携 } \\
\hline & & \multicolumn{2}{|c|}{ 全体 } & \multicolumn{2}{|c|}{ 隣接連携 } & \multicolumn{2}{|c|}{ 遠隔連携 } \\
\hline & & 事業数 & 比率 $(\%)$ & 事業数 & 比率 $(\%)$ & 事業数 & 比率 (\%) \\
\hline \multicolumn{2}{|r|}{ 総計 } & 73 & $(100.0)$ & 34 & $(100.0)$ & 39 & $(100.0)$ \\
\hline \multirow{3}{*}{$\begin{array}{c}\text { 事業 } \\
\text { 主体数 }\end{array}$} & 2団 & 31 & $(42.5)$ & 12 & $(35.3)$ & 19 & $(48.7)$ \\
\hline & 3団体 & 42 & $(57.5)$ & & $(64.7)$ & 20 & $(51.3)$ \\
\hline & 平均值/中央 & \multicolumn{2}{|c|}{$3.6 / 3.0$} & \multicolumn{2}{|c|}{$3.7 / 3.0$} & \multicolumn{2}{|c|}{$3.5 / 3.0$} \\
\hline \multirow{5}{*}{$\begin{array}{l}\text { 交付 } \\
\text { 予定額 }\end{array}$} & 1千方 & 21 & $(28.8)$ & 10 & $(29.4)$ & 11 & $(28.2)$ \\
\hline & 5千万未満 & 28 & $(38.4)$ & 14 & $(41.2)$ & 14 & $(35.9)$ \\
\hline & 1億牙 & 13 & (17.8) & 4 & & 9 & $(23.1)$ \\
\hline & 1億上 & 11 & $(15.1)$ & 6 & $(17.6)$ & 5 & $(12.8)$ \\
\hline & 平均値/中央値 (千円) & 41,226 & 25,500 & 37,825 & 20,523 & 44,190 & 30,600 \\
\hline
\end{tabular}

表 4 市町村別 · 人口規模別の事業参画率

\begin{tabular}{|c|c|c|c|}
\hline & \multicolumn{2}{|c|}{ 越境連携事業 } & \multirow{2}{*}{ 自治体数 $* *$} \\
\hline & 参画偻 & 比率 $(\%)$ & \\
\hline 全体 & 188 & $(10.8)$ & 1741 \\
\hline 町村 & 72 & $(7.8)$ & 928 \\
\hline 5千人未満 & 15 & (5.6) & 267 \\
\hline 5千～1万人未満 & 19 & $(7.9)$ & 242 \\
\hline 1 3万人未満 & 33 & $(9.3)$ & 354 \\
\hline 3〜5万人满 & 5 & $(7.7)$ & 65 \\
\hline 市* & 116 & (14.3) & 813 \\
\hline 1 3万人未満 & 9 & (9.9) & 91 \\
\hline 3〜5万人未満 & 27 & (14.9) & 181 \\
\hline 5～10万人未満 & 35 & (13.5) & 259 \\
\hline 10３0万人未満 & 37 & (18.7) & 198 \\
\hline 30 万人以上 & 8 & (9.5) & 84 \\
\hline
\end{tabular}

*東京都特別区は市に含んだ **国勢調査データでは東京都特別区部は1市として計算しているものを23区に修正 ****複数回採択または複数事業に参加している自治体も1自治体でカウントしている

行政構造において越境連携する事は難しい。 そのため, 越境して市 町村が連携する事業は「県・市町村連携」及び「県連携」と比較して, 特に先駆性があると考える。 そこで, 本章では市町村連携による越 境連携事業に着目して事業構成を分析し, 先駆的な事業事例注5) を取 り上げて事業実施の経緯を明らかにする.

\section{1 市町村連携による越境連携事業}

市町村が連携して実施する越境連携事業は 73 事業ある. そのうち, 隣接連携が 34 事業, 遠隔連携が 39 事業で遠隔連携による事業が多い.

市町村連携による越境連携事業の事業主体数，交付予定額につい てみる（表 3)。まず，事業主体数については，隣接連携では「3 団 体以上」による事業が $64.7 \%$ で「2 団体」による事業の $35.3 \%$ と比 較して高い，一方，遠隔連携では「2団体」による事業と「3 団体以 上」による事業は $48.7 \%$ と $51.3 \%$ でほぼ同率である。事業主体数の 平均值は隣接連携が 3.7 で遠隔連携が 3.5 であり，遠隔連携の方が 少数主体で実施されている. 交付予定額は隣接連携と遠隔連携とも に「1 千万〜 5 千万円未満」の事業が最も多く，平均值では遠隔連携 が 44, 190 千円で隣接連携の 37, 825 千円よりも高い.

表 4 は市町村連携による越境連携事業に参画している自治体の市 町村別・人口規模別の事業参画率である。市町村連携による越境連 携事業に参画している自治体は全体で $10.8 \%$ であり，市の参画率が $14.3 \%$ で町村の参画率 $7.8 \%$ より多い. 特に，10〜30 万人未満の市 の参画率が $18.7 \%$ で最も多い結果となった。

\section{2 市町村連携による越境・隣接連携事業}

市町村連携による越境・隣接連携事業の一覧を表 5 に事業の分布 を図 2 に示す．事業数は 34 事業であり，先行で 4 事業，加速化で 18 事業, 加速化 2 次で 1 事業, 推進 1 で 4 事業, 推進 2 で 7 事業が採 択されている。

表 5 及び図 2 で事業が実施されているブロックの範囲をみると， 1 〜 2 ブロック内で事業が実施されている.ブロック別に事業数をみ ると東北圈 5 事業, 首都圏 6 事業, 北陸圏 3 事業, 中部圈 7 事業, 近畿圈 8 事業, 中国圈 11 事業, 四国圈 2 事業, 九州圈 5 事業と各ブロッ クで事業が実施されており，特に中国圈が多い.

越境・隣接連携事業は県境地域で実施される ${ }^{\text {注6) }}$. 例えば, 「「食」と「連 携」による東九州新時代創生事業〜東九州（延岡・佐伯）バスク化 構想〜」は, 宮崎県延岡市と大分県佐伯市の県境地域での事業である.

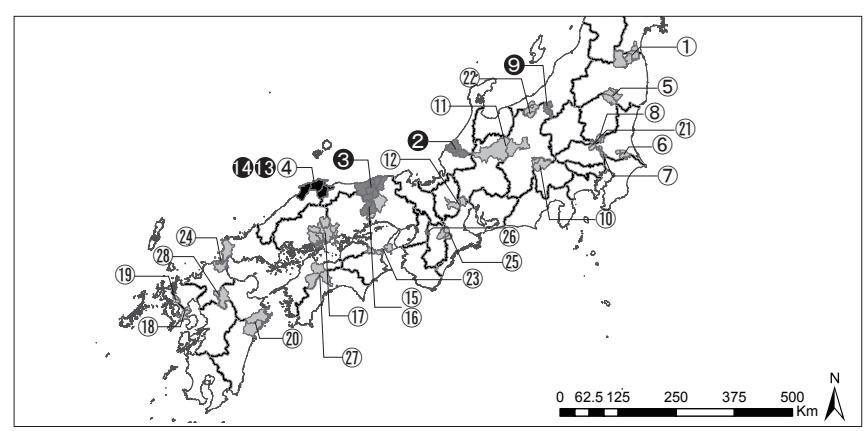

図 2 市町村連携による越境・隣接連携事業の分布

表 5 市町村連携による越境・隣接連携事業の一覧

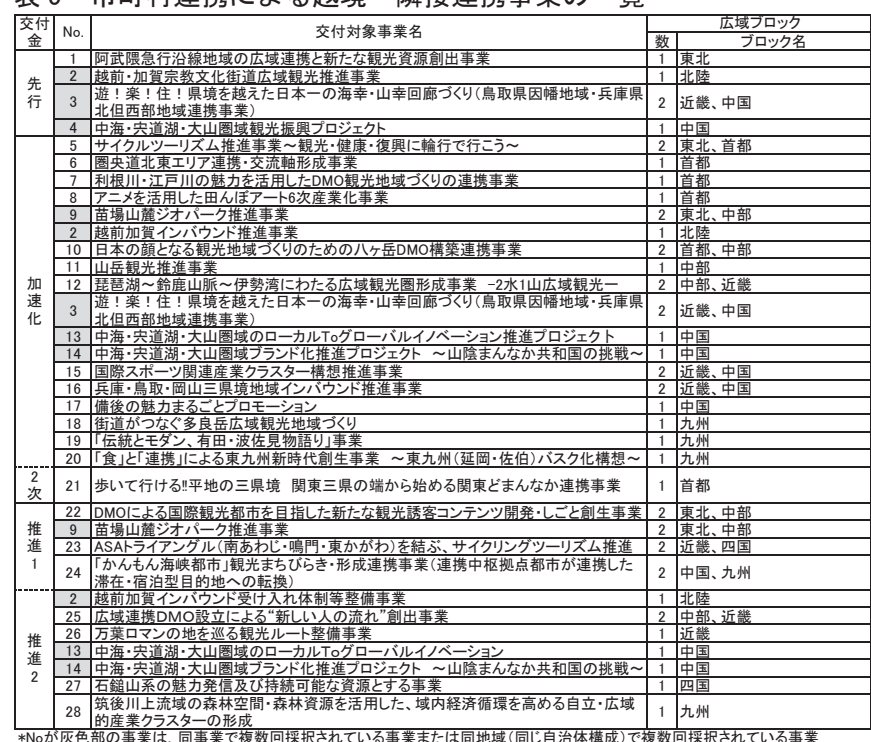

本事業の経緯について延岡市役所に電話でヒアリングした。延岡 市が 2015 年 11 月に開催した「エンジン 01 文化戦略会議オープンカ レッジinのべおか」注7) で延岡市の食資源が再評価され食によるま ちづくりが提唱された，その際に，食によるまちづくりの参考とし てバスク地方が紹介された。スペイン・フランス国境地帯であるバ スク地方と宮崎県延岡市と大分県佐伯市の県境地域は人口規模も同 程度であることなど地域特色に共通点があることから「東九州バス ク化構想」が生まれている.

延岡市と佐伯市は本事業以前から，「大分・宮崎県境地域開発促進 協議会」や「東九州伊勢えび街道」,「延岡市・佐伯市災害相互応援協定」 等で連携しており ${ }^{12)}$ ，また佐伯市は先行して食のまちづくりを実践 していたこともあり，延岡市から佐伯市に連携を打診して地方創生 関係交付金を活用した連携事業の実施に至っている.

このように県境地域は，道路などの地域基盤整備の促進や観光連 携の必要性からすでに越境連携が行われている地域も多く，これま での連携を背景に交付金を活用して連携事業が実施されていること が分かる.

\section{3 市町村連携による越境・遠隔連携事業}

市町村連携による越境・遠隔連携事業の一覧を表 6 に事業の分布 を図 3 に示寸．事業数は 39 事業であり，先行で 5 事業，加速化で 24 事業, 推進 1 で 6 事業, 推進 2 で 4 事業が採択されている.

表 6 から広域ブロック別に事業数をみると北海道 10 事業, 東北圈 23 事業, 首都圈 13 事業, 北陸圈 7 事業, 中部圈 10 事業, 近畿圈 9 事業, 中国圈 6 事業, 四国圈 4 事業, 九州圈 11 事業と東北圈の事業数が多い. 
事業が実施されているブロックの範囲をみると，1ブロックでの事業 が 8 事業, 2 ブロックで 20 事業, 3 ブロックで 6 事業, 4 ブロック以 上で 5 事業（最大は「2020 年東京オリンピック・パラリンピックを 活用した地域活性化推進首長連合 新虎通り活用事業」の8ブロック) とブロックを跨いで広範囲で事業が実施されている.

また，交付金に複数回採択されブロックが拡大している事業もあ る。例えば，「「大人の社会塾」を中心とした人材育成による地域活 性化事業」（No. 10, 30）は加速化交付金で3ブロックであったが推進 交付金では 6 ブロックに拡大している事業である. 加速化では山形 県高畠町, 山形市, 福島県会津若松市, 喜多方市, 三島町, 東京都 八丈町，富山県高岡市による事業として採択され，推進交付金では 同事業の拡大 - 深化版として山形県高畠町, 北海道更別村, 福島県 会津若松市, 東京都八丈町, 富山県高岡市, 徳島県上板町, 宮崎県 小林市による事業として採択されている。「大人の社会塾」（熱中小 学校）は山形県高畠町が廃校を活用して首都圈等の企業経営者や第

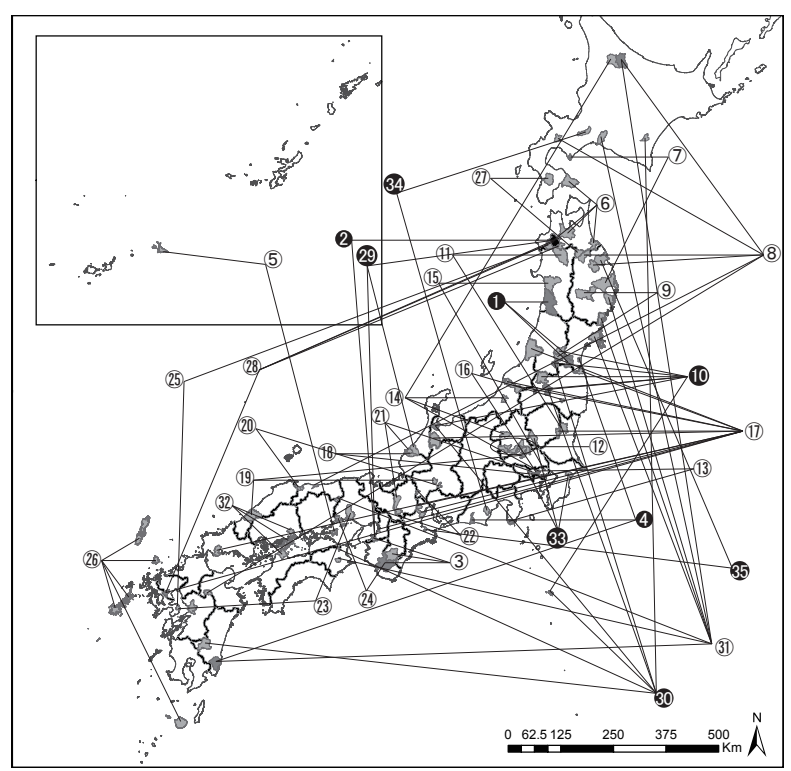

図 3 市町村連携による越境・遠隔連携事業の分布

表 6 市町村連携による越境・遠隔連携事業の一覧

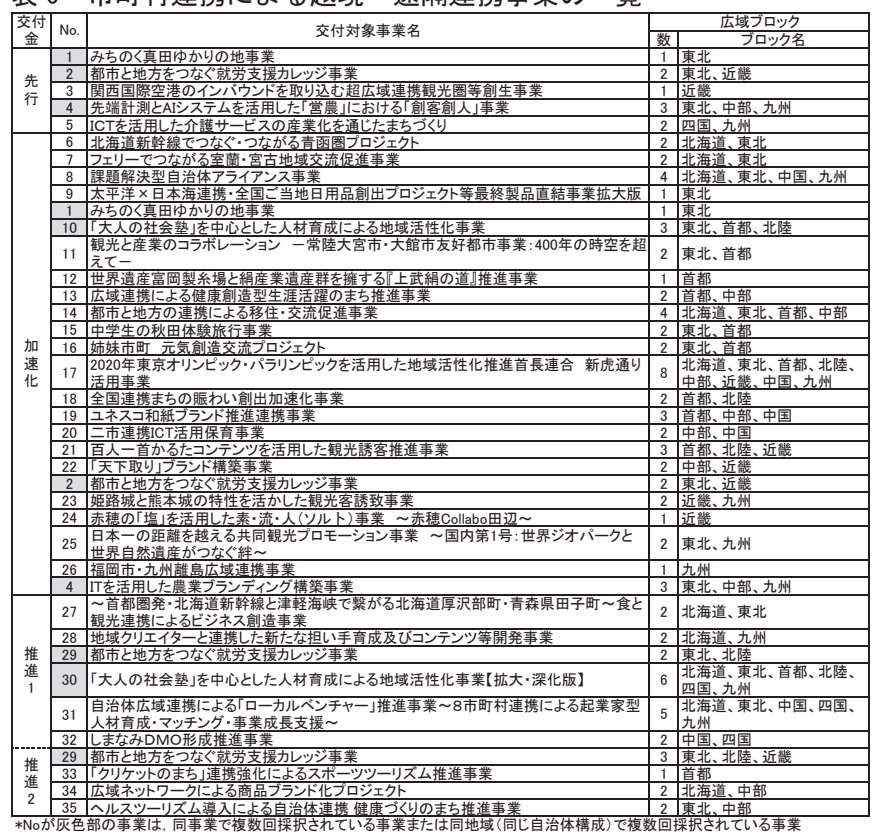

一線で活躍する大学研究者を講師に招き, 起業・創業へのアプローチ, ビジネススキルアップ, 観光開発, 地場産業の振興などの講演を通じ, 人材育成する事業である.

本事業の経緯について高畠町に電話でヒアリングした，当初は高 畠町の事業として廃校利活用事業の実施を検討していたところに地 方創生先行型交付金の募集があり交付金事業（通常事業）として応 募したところ採択された. 本事業の第 1 期生の生徒と講師から「自 分たちの地元でもやりたい」という要望と事業に関心を持った自治 体から連携の打診があり，加速化交付金に連携事業として応募する ことになった．観光振興や廃校利活用といった共通の課題を有する 自治体と連携している，そして，推進交付金では連携自治体の一部 入替はあるものの, ブロックを拡大している.

同様に「都市と地方をつなぐ就労支援カレッジ事業」(No. 2, 29) も先行と加速化，推進交付金で採択されており先行型と加速化で 2 ブロックであったものが，推進で 3 ブロックに連携が拡大している 特徵的な取り組みである.

以上の事例のように，地方創生関係交付金を活用して越境連携事 業が生まれ，さらに交付金を継続的に活用して連携を拡大している 事業があることが分かった。

\section{4. 市町村連携による越境・遠隔連携事業のプロセスと連携の効果}

本章では, 市町村連携による越境連携事業で特徵的な遠隔地の自 治体間連携でかつ先進的な取り組みとして先行, 加速化, 推進交付 金で採択され，実施主体が拡大した事業である「都市と地方をつな ぐ就労支援カレッジ事業」を先駆的事業事例注5) として取り上げる. 本事業の実施主体である青森県弘前市へのヒアリングと実施計画書 から事業概要, 連携の経緯, 事業の効果等について明らかにする. なお, 弘前市はその他の遠隔連携事業でも採択されている注8).

\section{1 事業概要}

「都市と地方をつなぐ就労支援カレッジ事業」は遠隔地の都市間連 携による農業人材育成を目的とした事業であり, 大阪周辺の就農希 望の若年無業者等を大阪府泉佐野市で受け入れ, 最低限の農業技術 の習得並びに地方での暮らし方を習得させた後に，担い手が不足す る弘前市のリンゴ農家に場所を移して農業の実地研修を行う。就労 につながりにくい人材に対して, 両市が連携して, 個々の状況や能 力に応じた体験型学習による支援を行うことで就農に結び付ける内 容になっている (図 4 事業概要).

\section{2 連携の経緯}

弘前市は地方創生で広域連携が重視されている点に着目し, 交 付金事業の募集をきっかけに広域連携事業の先行事例等についてリ サーチを進めていた。 そして, 大阪府豊中市と高知県土佐町が連携 して取り組んでいる就労支援の事例 ${ }^{13)}$ について事業関係者のいる「大 阪地域職業訓練センター (A’ワーク創造館)」に問合せをした。大 阪地域職業訓練センターの構成員 ${ }^{\text {注 }}$ ) である「NPO 法人おおさか若者 就労支援機構」(以下, 支援機構) と支援機構の事業から生まれた「株 式会社泉州アグリ」は，大阪府泉佐野市と連携して就職困難者や若 年者の人材育成事業を実施していた。「支援機構」は参加者の窓口, 生活訓練・相談対応の役割を担い,「泉州アグリ」は研修生の農業体 験研修,「大阪地域職業訓練センター」は企業への多様な人材活用方 策の提案や自治体における就労支援の仕組みづくりの役割を担って 
いる。「都市と地方をつなぐ就労支援カレッジ事業」では上記 3 団体 で構成する共同企業体「泉佐野アグリカレッジ」が事業を委託して いる.

弘前市は泉佐野市を訪れ取り組みを視察した後に，連携事業を打 診して先行型交付金の応募一と進展した。連携事業に繋がった要因 は互いにメリットがあったためである。つまり，弘前市は都市部の 研修生の受入に加えて泉佐野市が先行して取り組んでいる就労支援 のノウハウを得ることができること, 一方, 泉佐野市は就労支援に 関する事業で先行型交付金への応募を検討していたこともあり，弘 前市と連携することで研修先の拡充というメリットがあったことか ら連携事業へと進展した（図 4 連携の経緯).

\section{3 連携の拡大と相互の影響}

「都市と地方をつなぐ就労支援カレッジ事業」は都市と地方が遠隔 連携して共通課題である就労支援に取り組む特徵的な取組みであっ たことから, 首都圈での発表の場などで情報発信する機会が増えた. その結果, 同様の問題に悩む石川県加賀市から連携の打診があり, 推進交付金事業で連携が拡大した。

本事業は就農希望の若年無業者等を泉佐野市で受け入れ，最低限 の農業技術の習得並びに地方での暮らし方を習得させた後に, 弘前 市と加賀市に場所を移して農業の実地研修を行うといった「就労支 援カレッジ」がメインであるが，それに加えて弘前市と加賀市では 「ワーク・チャレンジプログラム推進体制構築」と「ひとり親家庭応 援会社創業支援」,「ローカルベンチャー育成事業」,「シェアオフィ ス・シェアハウスの整備」といった事業も併せて実施している（図 4 事業内容)。「ワーク・チャレンジプログラム推進体制構築」は泉佐 野市の就労支援のノウハウをもとに自地域内の就労支援プログラム の作成と体制づくりを構築する事業で，「ひとり親家庭応援会社創業 支援」はワーク・チャレンジプログラムをモデル的に展開していく 事業である.そして,「ローカルベンチャー育成事業」は加賀市が先
行して実施している事業で, 推進交付金では弘前市も加賀市を参考 に事業に取組み，加賀市はこれまで弘前市が実践してきた「就労支 援カレッジ」と「ワーク・チャレンジプログラム推進体制構築」、「ひ とり親家庭応援会社創業支援」に取組んでいく予定である. 以上の ように, 連携先相互の先行する事業のノウハウを互いに吸収してい ることが分かる。

また, 2016 年 6 月には事業で連携する弘前市と泉佐野市, さらに, ひとり親移住支援に先行して取組んでいた島根県浜田市の 3 市長が 呼びかけ人となり,「地方就労・自立支援事業推進プラットフォーム 呼びかけ文」を発信して,「自治体連携推進会議」を設立した。自治 体連携推進会議の事務局である大阪地域職業訓練センターに電話ヒ アリングしたところ，この呼びかけに市町村や NPO, 地域団体等の 94 団体（2017 年 3 月末時点）から問合せがあり, 勉強会を開催するな ど連携を推進していることが分かった。

このように地方創生関係交付金をきっかけに弘前市と泉佐野市の 越境・遠隔連携事業が生まれ，そこに加賀市が加わるなど連携が桩 大している. また, 同様の課題を持つ自治体間の連携・交流のため のプラットホームが形成されたことで, 今後連携・交流活動が深化 し課題解決に向けた取り組みの進展が期待できる.

\section{5. 総括}

本研究は，地方創生関係交付金を活用した越境連携事業に着目し て，交付金で採択された越境連携事業の把握と連携から実施までの プロセス及びその連携効果を明らかにしたものである，得られた知 見を以下にまとめる.

(1)地方創生関係交付金で採択された広域連携事業は 592 事業であり, その内，越境連携事業が 118 事業（19.9％) あることを確認した.

(2)事業主体の位置関係に着目して隣接連携と遠隔連携で細分した結 果, 隣接連携が 60 事業 (50.8\%) で遠隔連携が 58 事業 (49.2\%) であっ

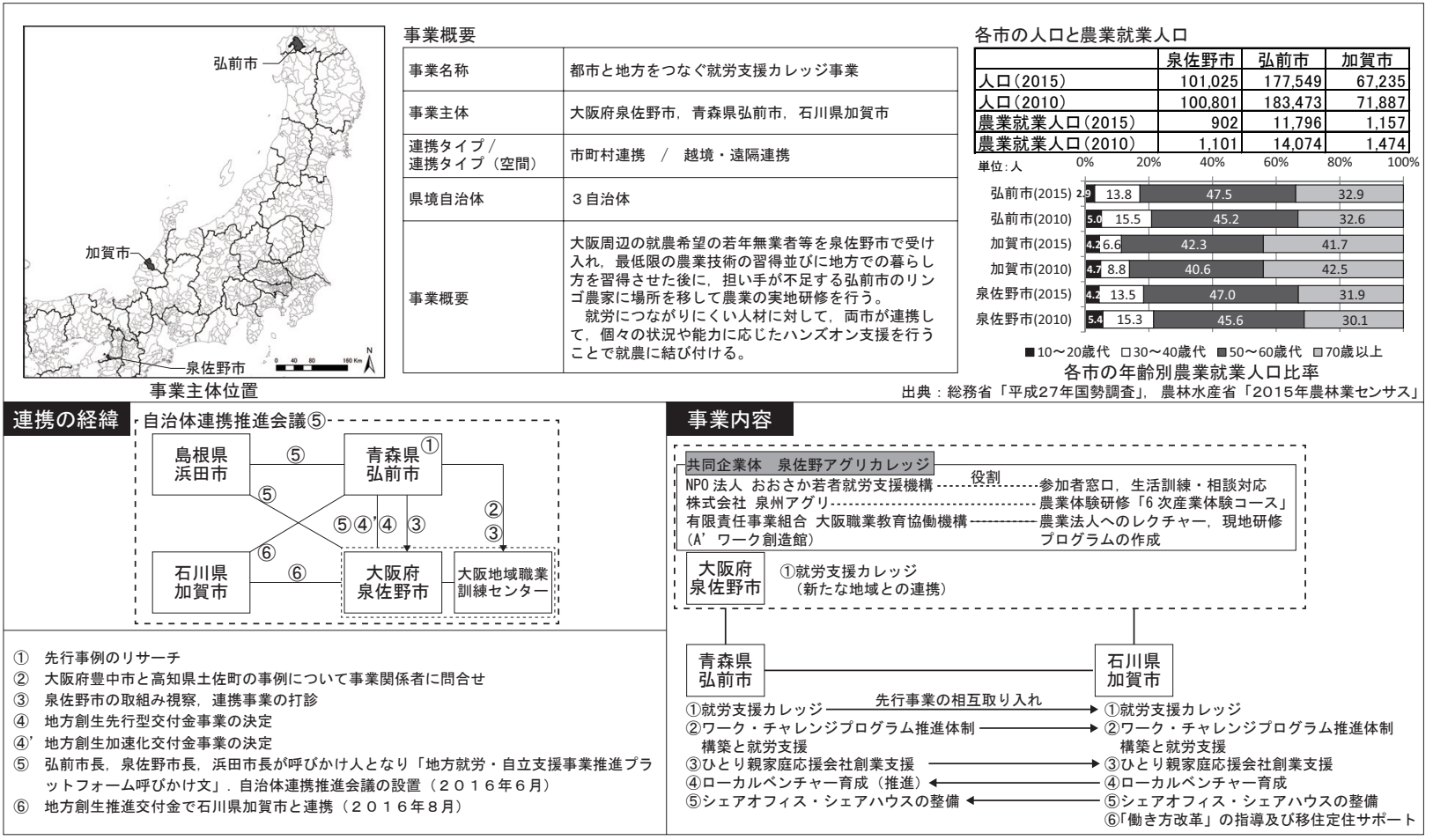

図 4 市町村連携による越境・遠隔連携事業の事例 
た.

(3)広域ブロック別に越境連携事業の実施状況を見た結果, 越境連携 事業への関与が最も高いブロックは東北圈と九州圈であり, 東北圈 は特に遠隔連携事業の割合が高く, 一方で九州圈は隣接連携と遠隔 連携のどちらの割合も高いといった特徴があった。

(4)市町村連携による越境連携事業は 73 事業（隣接連携 34 事業, 遠 隔連携 39 事業) あり, 全国の市町村の約 1 割が参画している.

(5)越境・隣接連携事業の「食」と「連携」による東九州新時代創生 事業〜東九州（延岡・佐伯）バスク化構想〜」では, 宮崎県延岡市 と大分県佐伯市の県境地域で越境連携がすでに実施されていること もあり，これまでの連携をべースに交付金を活用して事業が生まれ ていた.

(6)越境・遠隔連携事業の「「大人の社会塾」を中心とした人材育成に よる地域活性化事業」や「都市と地方をつなぐ就労支援カレッジ事業」 の事例では，交付金が契機となり新たな自治体間連携が生まれ，交 付金を活用して連携を拡大していることを確認した。特に，「都市と 地方をつなぐ就労支援カレッジ事業」では, 連携自治体が中心になっ て共通課題を有する自治体間の連携・交流のためのプラットホーム を形成するプロセスを把握できた.

地方創生関係交付金では地域間連携を事業採択の評価基準として 重視したことから 592 事業の広域連携事業が生まれ, そのうち 118 事業の越境連携事業が生まれている.これは交付金が広域連携及び 越境連携の促進に有効であったといえる。広域連携の促進において は交付金の一層の活用が望まれる.

しかしながら, 越境連携は容易に成立することはなく, 事例とし て取り上げた 3 事例の連携経緯から越境連携の成立要件をみると, 第 1 に共通の課題や資源を有して連携により互いに相乗効果が見込 めること, 第 2 に歴史的な越境連携の実績や仲介役が存在すること が越境連携が成立する上で重要となっている. 特に, 越境・遠隔連 携では, 連携先となる自治体のマッチングが課題としてヒアリング の中でも挙がっており, 例えば全国の先行事業の情報集約・共有を 図り事業主体（特にキーパーソン）と自治体の仲介を担う全国組織 が必要である.

今回の分析で交付金に採択された越境連携事業の 5 割が遠隔連携 事業であることは注目すべき点であり, 共通課題や資源を有する他 県の自治体と連携する越境・遠隔連携の需要が高いといえる. その ため, 今後の交付金の活用では遠隔連携に着目していく必要がある.

また，交付金によって多数の越境連携事業が生まれたが，今後は 新規事業だけではなく,「都市と地方をつなぐ就労支援カレッジ事業」 の事例のように事業実施主体が中心となって共通課題を有する自治 体間で連携交流できるプラットホームを形成するなどの連携の発展 にも注目していくことが重要である.

今後の研究課題としては, 地方創生関係交付金で実施されている すべての越境連携事業を対象に越境連携事業の連携から実施までの プロセスについて調査し全体像を明らかにする必要がある。特に, 越境連携事業のキーパーソンの把握とその役割について分析したい.

\section{謝辞}

本研究は, 文部科学省共同利用・共同研究拠点「越境地域政策研究 拠点」愛知大学三遠南信地域連携研究センターの基盤研究の成果の
一部である. 本研究に関して弘前市ひろさき未来戦略研究センター, 延岡市役所, 高畠町役場, 大阪地域職業訓練センターにご協力頂いた. ここに記して謝意を表す.

\section{補注}

注 1）地方創生関係交付金は 2016 年 12 月時点までに，地方創生先行型交付金 (2015 年 11 月採択), 地方創生加速化交付金（1 次は 2016 年 3 月, 2 次 は 2016 年 8 月採択), 地方創生推進交付金（第 1 回は 2016 年 8 月, 第 2 回は 2016 年 11 月採択）が実施されている。

注 2）先駆性の評価基準には「政策間連携」，「地域間連携」「官民協働」，「事 業推進主体の形成」「政策 5 原則等」がある. 各交付金で自治体が申請 できる事業数の目安は定められており, 先行型交付金と加速化交付金で は都道府県は 5 事業, 市町村は 2 事業を目安としており, 広域連携を含 む事業を申請する場合はこの限りではなかった.2016年度の推進交付 金(第 1 回) から都道府県は 5 事業, 市町村は 2 事業を目安としており, 市町村については広域連携を含む事業を申請する場合は 1 事業分追加し て 3 事業申請できるように定められた

注 3）例えば，定住自立圈に関する研究には片山健介，伊藤弘基，城所哲夫： 市町村間の「緩やかな連携」に基づく広域ガバナンスの形成と地域政策 に関する研究一定住自立圈構想に着目して一, 都市計画論文集, Vol. 48, No. $1,2013.4$ 等がある.

注 4）広域地方計画の圈域については, 「国土形成計画法施行令」(http://law. e-gov. go. jp/htmldata/H18/H18SE230.html) を参照.

注 5） 3 章及び 4 章で取り上げた事例は，事業数の最も多い加速化交付金に採 択された事業で 2 章 2 節の分析結果より越境連携事業への関与が高い 東北圈と九州圈で実施されている事業であること,さらに交付金に複 数回採択されている，あるいは「地方創生に係る特徽的な取組み事例」 (http://www. kantei. go. jp/jp/singi/sousei/pdf/kouhukin-jirei. pdf) に取り上げられている事業から選択した。

注 6）例えば, 3 団体以上で実施される事業の場合, 県境自治体 2 団体とその どちらかに隣接する非県境自治体（県境に接していない市町村）1 団体 で構成される事業も越境・隣接連携事業になる。

注 7)「エンジン 01 文化戦略会議オープンカレッジ」は, エンジン 01 文化戦略 会議が主催するイベントで会員と地域住民が交流する. 2015 年の延岡大 会では山本益博氏が大会委員長となり “食”をテーマに開催された。 ンジン 01 文化戦略会議は, 各分野の表現者・思考者たちが日本文化の さらなる深まりと広がりを目的に参集したボランティア集団.

注 8）弘前市が地方創生関係交付金で採択された越境・遠隔連携事業は「都市 と地方をつなぐ就労支援カレッジ事業」(先行, 加速化, 推進),「北海 道新幹線でつなぐ・つながる青函圈プロジェクト」(加速化), 「地域ク リエイターと連携した新たな担い手育成及びコンテンツ等開発事業」(推 進)がある。

注 9）大阪地域職業訓練センターの運営団体は有限責任事業組合大阪職業教育 協働機構であり, 就労支援等に取り組む 5 団体で構成されている。

\section{参考文献}

1）まち・ひと・しごと創生本部：「まち・ひと・しごと創生本部」について http://www. kantei. go. jp/jp/headline/chihou_sousei/ (2017.5.23 確認)

2) 小川勇樹, 高橋大輔: 越境地域の市町村間連携一県境市町村を対象とした 政策アンケート調查，越境地域政策への視点，pp. 47-54，2014.6

3）戸田敏行：越境地域の地域計画 - 県境地域を対象とした地域計画策定の可 能性，越境地域政策への視点，pp. $40-47,2014.6$

4）戸田敏行, 楊迪鋼, 大貝彰: 県境地域における地域連携組織とその活動実 態の分析, 日本建築学会計画系論文集, 第 587 号, pp. 89-96, 2005.1

5）吉田敏行, 大貝彰 : 愛知・静岡・長野県境地域における地域連携活動の実 態分析, 日本建築学会計画系論文集，第 602 号，pp. 137-144，2006.4

6）国土交通政策研究所: 県境地域を対象とした広域的な地域づくりに関する 研究〜県境地域の状況と県境を越えた連携の促進について〜, 国土交通政 策研究, 第 90 号, 2010.3

7）まち・ひと・しごと創生本部：地域活性化・地域住民生活等緊急支援交付 金（地方創生先行型）先駆的事業分（タイプ I）の交付対象事業の決定 について, http://www. kantei.go. jp/jp/singi/sousei/about/kouhukin/ index. html (2015.12.7 確認)

8）まち・ひと・しごと創生本部：地方創生加速化交付金（平成 27 年度補正） の交付対象事業の決定について, http://www. kantei.go.jp/jp/singi/ sousei/about/kouhukin/index. html (2016.7.19 確認)

9）まち・ひと・しごと創生本部：地方創生加速化交付金の交付対象事業の決 定（2 次募集分）について, http://www. kantei. go. jp/jp/singi/sousei/ about/kouhukin/index. html（2016.8.3 確認）

10）まち・ひと・しごと創生本部：地方創生推進交付金の交付対象事業の決 定（平成 28 年度第 1 回）について, http://www. kantei.go.jp/jp/singi/ sousei/about/kouhukin/index. html (2016.8.3 確認)

11）まち・ひと・しごと創生本部：地方創生推進交付金の交付対象事業の決 定（平成 28 年度第 2 回）について, http://www. kantei.go.jp/jp/singi/ sousei/pdf/h28-suisin2. pdf (2016.12.1 確認)

12）愛知大学三遠南信地域連携研究センター: 第 1 回全国越境地域政策シンポ ジウム「県境地域の新たな可能性」, 愛知大学三遠南信地域連携研究セン ター紀要, No. 1， pp. 7-23，2014.6

13）濱田健司：生活困窮者の農業就労訓練に関する地域間連携〜新たな農福連 携モデル〜，共済総研レポート，No. 146, pp. 66-73，2016.8

[2017 年 6 月 5 日原稿受理 2017 年 7 月 31 日採用決定］ 